\title{
Peptide-Driven Shape Control of Low-Dimensional DNA Nanostructures
}

\author{
Chan-Jin Kim, Ji-eun Park, Xiaole Hu, Shine K. Albert, and So-Jung Park* \\ Department of Chemistry and Nanoscience, Ewha Womans University, 52 Ewhayeodae-gil, \\ Seodaemun-gu, Seoul 03760, Korea
}

* Correspondence to: sojungpark@ewha.ac.kr 


\section{Table of Contents}

Materials and instrumentations S3

Synthesis of $N$-acryloyl-Phe-OMe and $N$-acryloyl-Phe-Phe-OMe ................................................S4

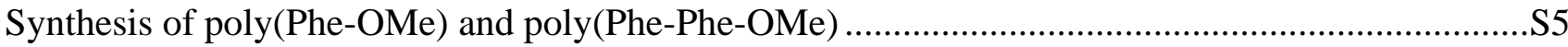

Synthesis of DNA- $b$-poly(Phe-OMe) and DNA- $b$-poly(Phe-Phe-OMe) …......................................

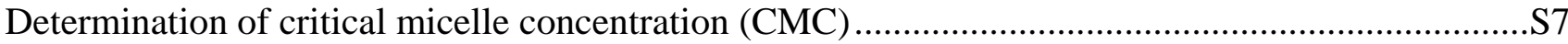

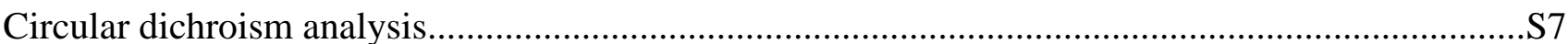

Synthesis of DNA functionalized gold nanoparticles (AuNP-DNA1 and AuNP-DNA1')................S7

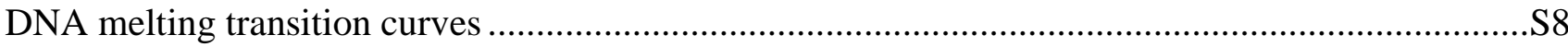

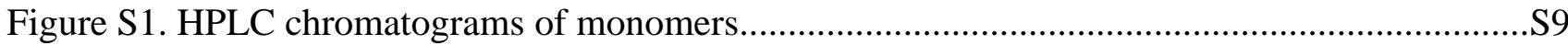

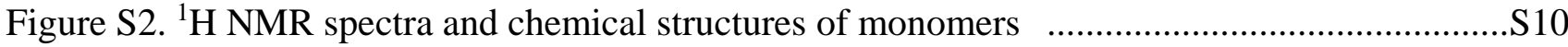

Figure S3. GPC chromatogram of synthesized polymers .........................................................S11

Table S1. Molecular weights of synthesized polymers ................................................................

Figure S4. ${ }^{1} \mathrm{H}$ NMR spectra and chemical structures of synthesized polymers.............................S12

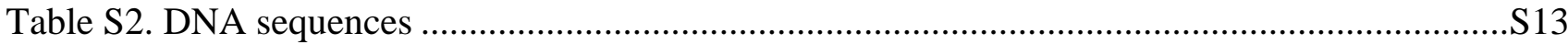

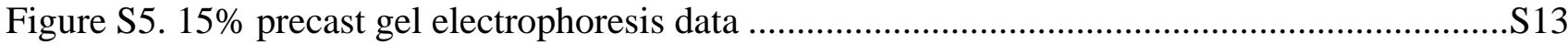

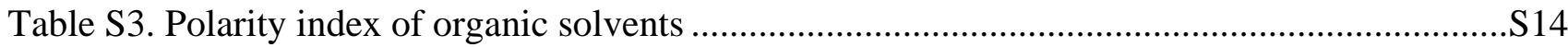

Figure S6. TEM images of one-dimensional assemblies .............................................................

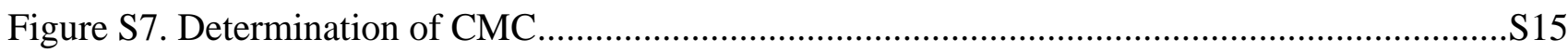

Figure S8. TEM images of $\mathrm{F}_{10} \mathrm{DA}$ and $\mathrm{FF}_{11} \mathrm{DA}$ in four organic solvents.....................................S15

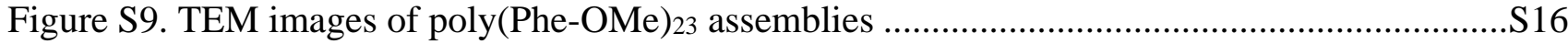

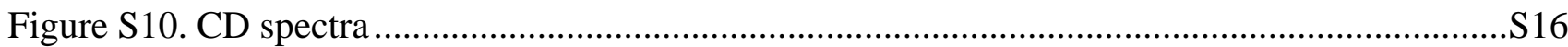

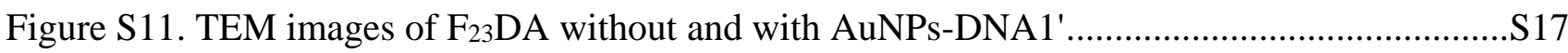

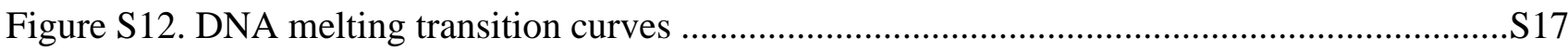




\section{Materials and instrumentations}

FAM-labeled DNA1, Cy3 labeled DNA1', and thiol-modified oligonucleotides were purchased from Bioneer (Daejeon, Korea). Chemicals for gel electrophoresis such as 10X tris/borate/EDTA (TBE) buffer, $30 \%$ acrylamide/bis Sol. 29:1, ammonium persulfate, and TEMED $\left(N, N, N^{\prime}, N^{\prime}-\right.$ tetramethylethylenediamine) were purchased from Bio-Rad (Hercules, California, USA). High performance liquid chromatography (HPLC) grade water and acetonitrile were purchased from Daejung (Gyeonggi-do, Korea). All other reagents were purchased from Sigma-Aldrich Chemical Company (St. Louis, MO, USA). Ultrapure water (18.2 M $\Omega$ ) was used for all experiments. Synthesized monomers and hydrolysis products were analyzed using HPLC equipped with a UV detector (YL Instruments Co., Ltd., Gyeonggi-do, Korea). HPLC analysis was performed on the C18 column $(5 \mu \mathrm{m}$ particle size, $250 \times 4.6 \mathrm{~mm}, 80 \AA$ pore size) (Phenomenex, CA, USA) using a gradient mode with water containing $0.05 \%$ trifluoroacetic acid (TFA) and acetonitrile containing $0.05 \%$ TFA. The flow rate, the operating temperature, and UV wavelength for detection were set at $1 \mathrm{~mL} / \mathrm{min}, 35$ ${ }^{\circ} \mathrm{C}$, and $254 \mathrm{~nm}$, respectively. Transmission electron microscopy (TEM) measurements were performed on a JEM-2100F electron microscope (JEOL Ltd., Tokyo, Japan) operating at $200 \mathrm{kV}$ accelerating voltage. Dynamic light scattering (DLS) measurements were performed using Zetasizer Nano-ZS (Malvern Instruments, Malvern, UK) with a $632.8 \mathrm{~nm}$ laser at a scattering angle of $173^{\circ}$. Fluorescence microscope images were collected in the green channel with $\lambda_{\mathrm{ex}}=488 \mathrm{~nm}$ and $\lambda_{\mathrm{em}}=$ 495-550 nm by using Olympus FV1000-IX81 confocal laser scanning microscope (Olympus, Tokyo, Japan). Gel permeation chromatography (GPC) measurements (Shimadzu, Kyoto, Japan) were performed with polystyrene standards setting at $40{ }^{\circ} \mathrm{C}$ with a flow rate of $1 \mathrm{~mL} / \mathrm{min}$ using THF as eluent to determine molecular weights $\left(\mathrm{M}_{\mathrm{n}}\right)$ and polydispersity index (PDI) of synthesized polymers. Chemical structures of synthesized monomers and polymers were determined by proton nuclear magnetic resonance $\left({ }^{1} \mathrm{H}\right.$ NMR) spectra, which were recorded on a Bruker Advance $300 \mathrm{MHz}$ NMR spectrometer (Bruker Biospin Corp., Germany). 


\section{Synthesis of $N$-acryloyl-Phe-OMe and $N$-acryloyl-Phe-Phe-OMe}

For the synthesis of $\mathrm{N}$-acryloyl-Phe-OMe, $\mathrm{NH}_{2}$-Phe-OMe $(1.0 \mathrm{~g}, 4.6 \mathrm{mmol})$ was dissolved in DMF $(5 \mathrm{~mL})$, and then kept at $0{ }^{\circ} \mathrm{C}$ under nitrogen. After the addition of trimethylamine (TEA) $(711.0 \mu \mathrm{L}$, $5.1 \mathrm{mmol})$, the mixture was stirred for $30 \mathrm{~min}$. Acryloyl chloride $(414.0 \mu \mathrm{L}, 5.1 \mathrm{mmol})$ in $1 \mathrm{~mL} \mathrm{DMF}$ was added slowly to the mixture for $15 \mathrm{~min}$ at $0{ }^{\circ} \mathrm{C}$ under nitrogen. After $24 \mathrm{~h}$ reaction at room temperature, methylene chloride (MC) $(30 \mathrm{~mL})$ was added to the solution. The product ( $N$-acryloylPhe-OMe), which was dissolved in $\mathrm{MC}$, washed with water $(20 \mathrm{~mL}$, three times $)$ and dried over anhydrous $\mathrm{MgSO}_{4}$. After removal of $\mathrm{MC}$ by vacuum evaporation, product was dried in vacuum oven for overnight ( $N$-acryloyl-Phe-OMe, $991.0 \mathrm{mg}, 89.0 \%)$.

For the synthesis of Boc-Phe-Phe-OMe, Boc-Phe-OH (3.1 g, $11.6 \mathrm{mmol}), N$-hydroxysuccinimide (NHS) (1.6 g, $13.9 \mathrm{mmol})$, and $\mathrm{H}-\mathrm{Phe}-\mathrm{OMe} \cdot \mathrm{HCl}(3.0 \mathrm{~g}, 13.9 \mathrm{mmol})$ were dissolved in $\mathrm{MC}$, respectively. For the deprotonation of the amine groups, TEA (1940 $\mu \mathrm{L}, 1.39 \mathrm{mmol})$ was added to the $\mathrm{H}-\mathrm{Phe}-\mathrm{OMe} \cdot \mathrm{HCl}$ solution and then the solution was stirred for $5 \mathrm{~min} . \quad N, N$-dimethylformamide (DCC) $(2.9 \mathrm{~g}, 13.9 \mathrm{mmol})$ was added to the mixture of the three solutions, and the reaction was kept for $24 \mathrm{~h}$ at room temperature with stirring. After the reaction, the precipitate, $N, N^{\prime}$-dicyclohexylurea (DCU), was removed by filtration and $30 \mathrm{~mL}$ MC was added to the supernatant. Subsequently, the filtrate was washed with $1 \mathrm{M} \mathrm{HCl}(10 \mathrm{~mL}$, three times $)$ and water $(10 \mathrm{~mL}$, three times $)$ and then dried over anhydrous $\mathrm{MgSO}_{4}$. After removal of $\mathrm{MC}$ by vacuum evaporation, product was dried in a vacuum oven for overnight (Boc-Phe-Phe-OMe, $4.6 \mathrm{~g}, 82.1 \%$ ). Synthesized Boc-Phe-Phe-OMe (3.0 $\mathrm{g}, 7.0 \mathrm{mmol})$ was dissolved in $30 \mathrm{~mL}$ TFA/MC (1:1), and incubated at room temperature for overnight to remove the Boc group. After the vacuum evaporation of the solvent, $30 \mathrm{~mL} \mathrm{MC}$ was added to the residue and removed again by evaporation. The residue $\left(\mathrm{NH}_{2}-\mathrm{Phe}-\mathrm{Phe}-\mathrm{OMe}\right)$ was dissolved in $\mathrm{MC}$ $(30 \mathrm{~mL})$, washed with water $\left(10 \mathrm{~mL}\right.$, three times), and dried over anhydrous $\mathrm{MgSO}_{4} . \quad$ After removal of MC by vacuum evaporation, product was dried in vacuum oven for overnight $\left(\mathrm{NH}_{2}-\mathrm{Phe}-\mathrm{Phe}-\mathrm{OMe}\right.$, 
$2.0 \mathrm{~g}, 87.1 \%)$. For the synthesis of $\mathrm{N}$-acryloyl-Phe-Phe-OMe, $\mathrm{NH}_{2}-\mathrm{Phe}-\mathrm{Phe}-\mathrm{OMe}(1.0 \mathrm{~g}, 3.1 \mathrm{mmol})$ was dissolved in DMF (5 mL), and then kept at $0{ }^{\circ} \mathrm{C}$ under nitrogen. After the addition of trimethylamine (TEA) $(470.0 \mu \mathrm{L}, 3.4 \mathrm{mmol})$, the mixture was stirred for $30 \mathrm{~min}$. Acryloyl chloride $(274.0 \mu \mathrm{L}, 3.4 \mathrm{mmol})$ in $1 \mathrm{~mL}$ DMF was added slowly to the mixture for $15 \mathrm{~min}$ at $0{ }^{\circ} \mathrm{C}$ under nitrogen. After $24 \mathrm{~h}$ reaction at room temperature, $\mathrm{MC}(30 \mathrm{~mL})$ was added to the solution. The product $(N$ acryloyl-Phe-Phe-OMe) in MC was washed with water $(10 \mathrm{~mL}$, three times) and dried over anhydrous $\mathrm{MgSO}_{4}$. After removal of MC by vacuum evaporation, product was dried in vacuum oven for overnight ( $N$-acryloyl-Phe-Phe-OMe, $808.0 \mathrm{mg}, 67.8 \%)$.

\section{Synthesis of poly(Phe-OMe) and poly(Phe-Phe-OMe)}

Poly(Phe-OMe $)_{10}$ and poly(Phe-OMe $)_{23}$ were synthesized by the reversible addition-fragmentation chain transfer (RAFT) polymerization method. $N$-acryloyl-Phe-OMe $(0.43 \mathrm{~g}, 1.86 \mathrm{mmol}$ for Poly(Phe-OMe) 10 or $1.44 \mathrm{~g}, 6.19 \mathrm{mmol}$ for Poly(Phe-OMe)23) were dissolved in $5 \mathrm{~mL}$ DMF with an initiator, 4,4'-Azobis(4-cyanopentanoic acid) $(15.0 \mathrm{mg}, 37.2 \mu \mathrm{mol})$ and a chain transfer agent (CTA), 4-Cyano-4-[(dodecylsulfanylthiocarbonyl)sulfanyl]pentanoic acid $(2.1 \mathrm{mg}, 7.43 \mu \mathrm{mol})$ in a Schlenk flask equipped with a magnetic stirring bar. The solution was degassed by three freeze-pump-thaw cycles and then heated at $70{ }^{\circ} \mathrm{C}$ for $24 \mathrm{~h}$ with stirring. The polymerization was stopped by introducing the air into the flask. The resulting polymer was purified by reprecipitation into $300 \mathrm{~mL}$ ethyl ether/hexane (1:1) and isolated by filtration. The same procedure was repeated three times and the final precipitates were dried under vacuum overnight.

Poly(Phe-Phe-OMe) 11 was prepared by the similar procedure. $\quad \mathrm{N}$-acryloyl-Phe-Phe-OMe (2.36 g, $6.19 \mathrm{mmol}$ ) was dissolved in $5 \mathrm{~mL} \mathrm{1,4-dioxane} \mathrm{with} \mathrm{an} \mathrm{initiator,} \mathrm{4,4'-Azobis(4-cyanopentanoic} \mathrm{acid)}$ (25.0 mg, $61.9 \mu \mathrm{mol})$ and a chain transfer agent (CTA), 4-Cyano-4[(dodecylsulfanylthiocarbonyl)sulfanyl]pentanoic acid $(3.5 \mathrm{mg}, 12.4 \mu \mathrm{mol})$ in a Schlenk flask equipped with a magnetic stirring bar. The solution was degassed by three freeze-pump-thaw cycles 
and then heated at $70{ }^{\circ} \mathrm{C}$ for $24 \mathrm{~h}$ with stirring. The polymerization was quenched by introducing the air into the flask. The resulting polymer was purified by reprecipitation into $300 \mathrm{~mL}$ ethyl ether/hexane (1:2) and isolated by filtration. The same procedure was repeated three times and the final precipitates were dried under vacuum overnight.

\section{Synthesis of DNA- $b$-poly(Phe-OMe) and DNA- $b$-poly(Phe-Phe-OMe)}

DNA block copolymers were synthesized by the amide bond formation between carboxylic acid terminated polymers and 5'-amine-modified DNA1 attached on CPG beads. Amino acid based polymer $(42.0 \mathrm{mg}, 15.0 \mu \mathrm{mol} \text { for Poly(Phe-OMe) })_{10}, 85.5 \mathrm{mg}, 15.0 \mu \mathrm{mol}$ for Poly(Phe-OMe) $)_{23}$, or 66.0 $\mathrm{mg}, 15.0 \mu \mathrm{mol}$ for Poly(Phe-Phe-OMe) ${ }_{11}$ ) was dissolved in DMF with $N, N$-diisopropylethylamine (DIEA) $(26.1 \mu \mathrm{L}, 150 \mu \mathrm{mol})$ and HATU $(5.7 \mathrm{mg}, 15.0 \mu \mathrm{mol})$, and then the solution was vortexed for $10 \mathrm{~min}$ at room temperature in order to activate the carboxylic acid group in polymer. 5'-aminemodified DNA1 on CPG beads ( $0.5 \mu$ mol scale) was added to this mixture, which was then placed on an orbital shaker at $400 \mathrm{rpm}$ for overnight. The beads were filtered from the solution and then washed with $50 \mathrm{~mL}$ DMF, $50 \mathrm{~mL}$ chloroform, and $50 \mathrm{~mL}$ acetone to remove unreacted polymers. The resulting DNA block copolymers were cleaved from CPG beads by incubating them in $1 \mathrm{~mL}$ concentrated ammonium hydroxide at $55{ }^{\circ} \mathrm{C}$ for $5 \mathrm{~h}$. The treated $\mathrm{CPG}$ beads were filtered off and subsequently washed with $7 \mathrm{~mL}$ water and $5 \mathrm{~mL}$ DMF/DMSO/concentrated ammonium hydroxide $(1: 1: 0.05)$ to get a solution containing synthesized DNA block copolymers. This filtrate was dried by lyophilization and the crude sample was dissolved in $400 \mu \mathrm{L}$ water/glycerol (8:2) solution for purification by gel electrophoresis. The DNA block copolymer was purified by $15 \%$ polyacrylamide gel electrophoresis in $1 \mathrm{X}$ TBE buffer at $200 \mathrm{~V}$ for $40 \mathrm{~min}$. It remained in well of the gel by forming assemblies due to the amphiphilicity of DNA block copolymers. The gel containing DNA block copolymers was cut and extracted into water by incubation in water with vigorous stirring. The 
remaining gel species were removed from the DNA block copolymer solution by filtration $(0.2 \mu \mathrm{m}$ cellulose acetate membrane filter). The solution was dialyzed against water for 2 days to remove salts.

\section{Determination of critical micelle concentration (CMC)}

The CMC of DNA-b-poly(Phe-OMe) $)_{23}$ assemblies $\left(\mathrm{F}_{23} \mathrm{DA}\right)$ prepared in HFIP/water (1:9) was determined by measuring the scattered light intensity as a function of DNA- $b$-poly(Phe-OMe $)_{23}$ concentration. $^{1,2}$ The CMC value was determined from the intersection of the two best fit lines (i.e. $1 \mathrm{nM}-80 \mathrm{nM}$ and $180 \mathrm{nM}-500 \mathrm{nM}$ ) (Figure S7).

\section{Circular dichroism analysis}

CD spectra were recorded using a Jasco Model J-1500 circular dichroism spectrophotometer. The samples were loaded into a rectangular quartz cell with the light path length of $1 \mathrm{~mm}$. The concentration of poly(Phe-OMe)23 nanostructures prepared in HFIP/water (1:9) and ACN/water (1:9) was $70 \mu \mathrm{M}$.

\section{Synthesis of DNA functionalized gold nanoparticles (AuNP-DNA1 and AuNP-DNA1')}

Gold nanoparticles (AuNPs) were prepared by the widely used citrate reduction method. ${ }^{3} \mathrm{HAuCl}_{4}$ $(0.06 \mathrm{~g})$ was dissolved in $196 \mathrm{~mL}$ water $(0.78 \mathrm{mM})$ and then this solution was refluxed until boiling. $4 \mathrm{~mL}$ sodium citrate solution $(184 \mathrm{mM})$ was added to the solution under vigorous stirring. After 30 min, the color of the solution changed from faint yellow to deep red. The diameter of the synthesized AuNPs was determined to be $12.4 \pm 1.0 \mathrm{~nm}$ by TEM measurements and the concentration was calculated by measuring the optical density (OD) at $520 \mathrm{~nm}$ using the extinction coefficient of $2.11 \times$ $10^{8} \mathrm{M}^{-1} \mathrm{~cm}^{-1}$.

DNA-functionalized AuNPs were prepared using thiol-modified DNA strands following the procedure reported by Storhoff et al. ${ }^{5}$ The concentration of AuNPs and thiol-modified DNA were 
set to $8.5 \mathrm{nM}$ and $1.81 \mu \mathrm{M}$, respectively, and then this solution $(10 \mathrm{~mL})$ was put on an orbital shaker at $150 \mathrm{rpm}$ for $16 \mathrm{~h}$ prior to salt aging process. $100 \mathrm{mM}$ phosphate buffer ( $\mathrm{PB}, \mathrm{pH} 7,1 \mathrm{~mL})$ containing $1 \mathrm{M} \mathrm{NaCl}$ was slowly added to the solution at the rate of $123.5 \mu \mathrm{L}$ per 20 min until the final salt concentration reached $10 \mathrm{mM} \mathrm{PB}(\mathrm{pH} 7)$ and $100 \mathrm{mM} \mathrm{NaCl}$. The solution was kept at this condition for $40 \mathrm{~h}$ followed by centrifugation at $12,000 \mathrm{rpm}$ for $30 \mathrm{~min}$ to remove excess reagents. The supernatant was discarded and DNA-functionalized AuNPs were redispersed in 0.5X TBE buffer containing $50 \mathrm{mM} \mathrm{NaCl}$ at a final concentration of $50 \mathrm{nM}$.

\section{DNA melting transition curves}

DNA block copolymer assemblies $\left(\mathrm{F}_{23} \mathrm{DA}\right)$ were prehybridized with DNA1' in $0.3 \mathrm{M}$ PBS for $2 \mathrm{~h}$ before performing temperature-dependent FRET measurements. The concentration of DNA1 in DNA block copolymer assemblies and DNA1' were set to $100 \mathrm{nM}$, respectively. The temperature was increased from $20^{\circ} \mathrm{C}$ to $80{ }^{\circ} \mathrm{C}$ with a temperature gradient of $1{ }^{\circ} \mathrm{C} / \mathrm{min}$ with 1 min equilibration time at each temperature to obtain fluorescence spectra. The melting temperature was obtained by taking the peak position of the first derivative of the thermal denaturation curve. 

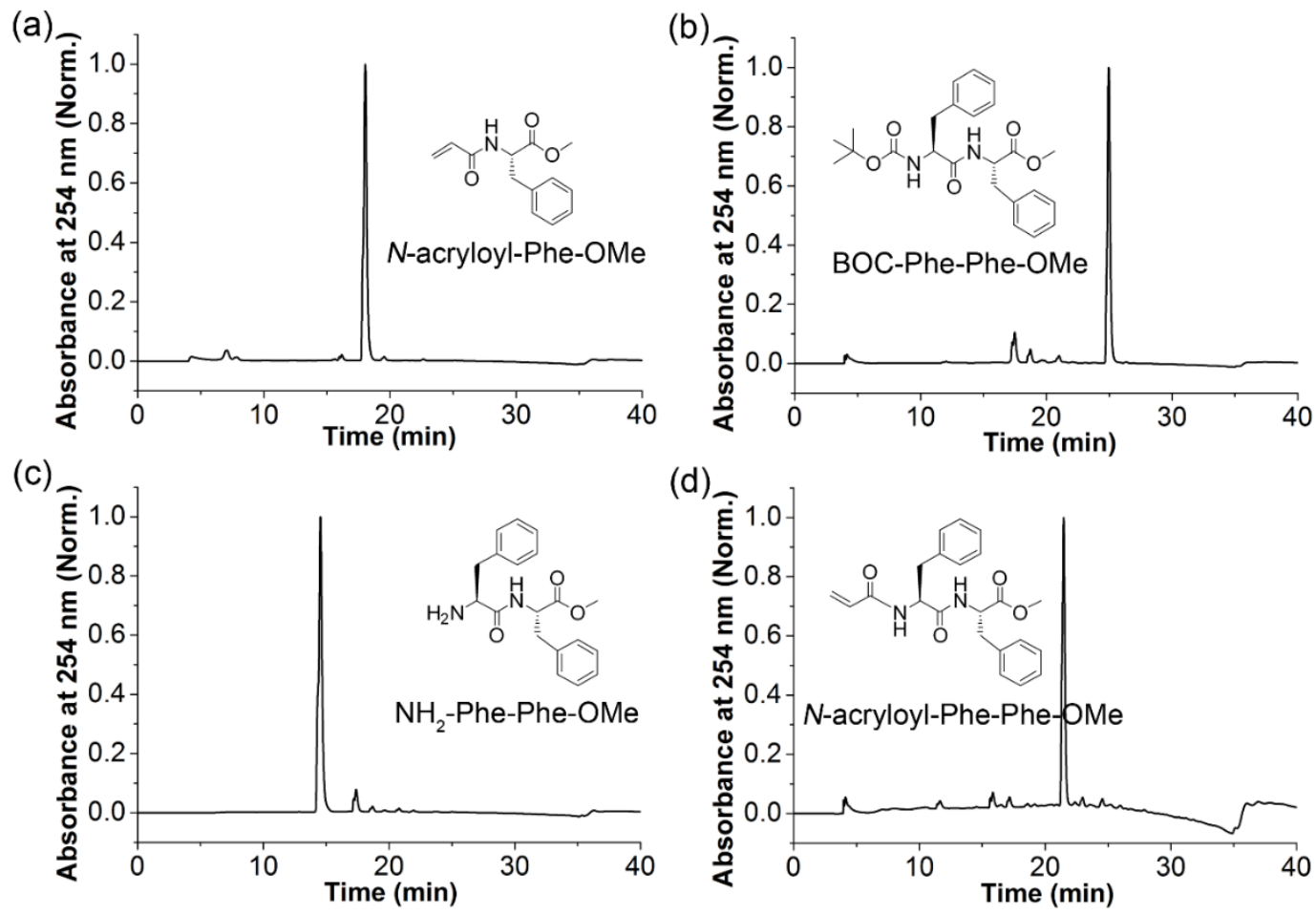

Figure S1. HPLC chromatograms of synthesized (a) $N$-acryloyl-Phe-OMe (RT = 18.0 min), (b) BocPhe-Phe-OMe (RT = $25.0 \mathrm{~min})$, (c) $\mathrm{NH}_{2}$-Phe-Phe-OMe (RT = $\left.14.5 \mathrm{~min}\right)$, and (d) $N$-acryloyl-Phe-Phe$\mathrm{OMe}(\mathrm{RT}=21.4 \mathrm{~min})$. 


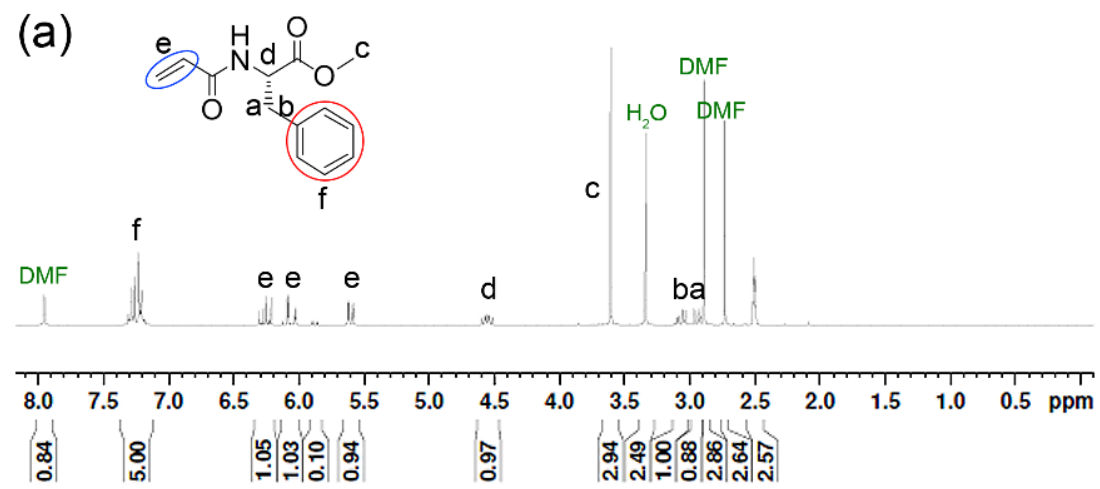

(b)

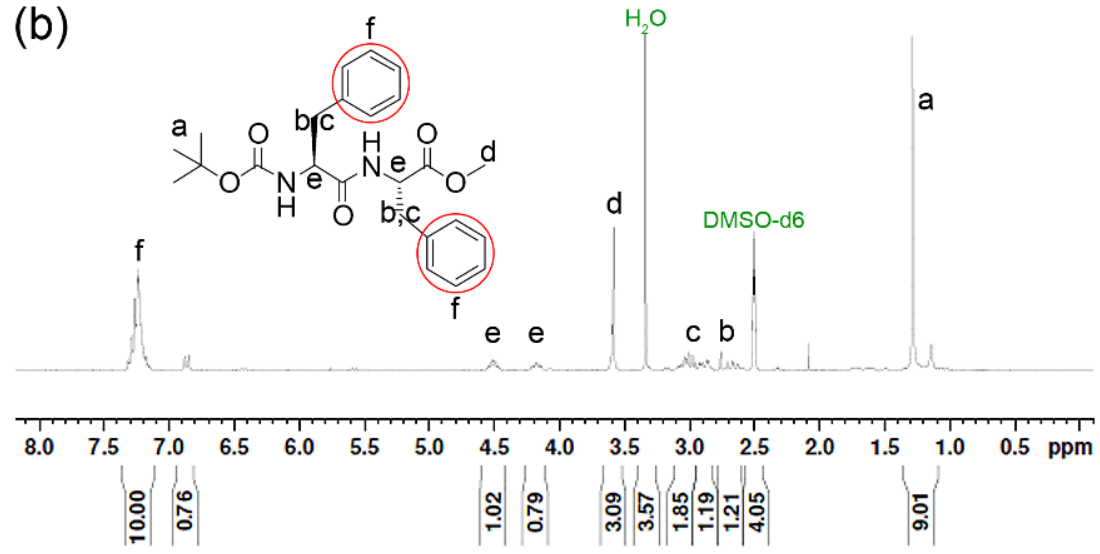

(c)

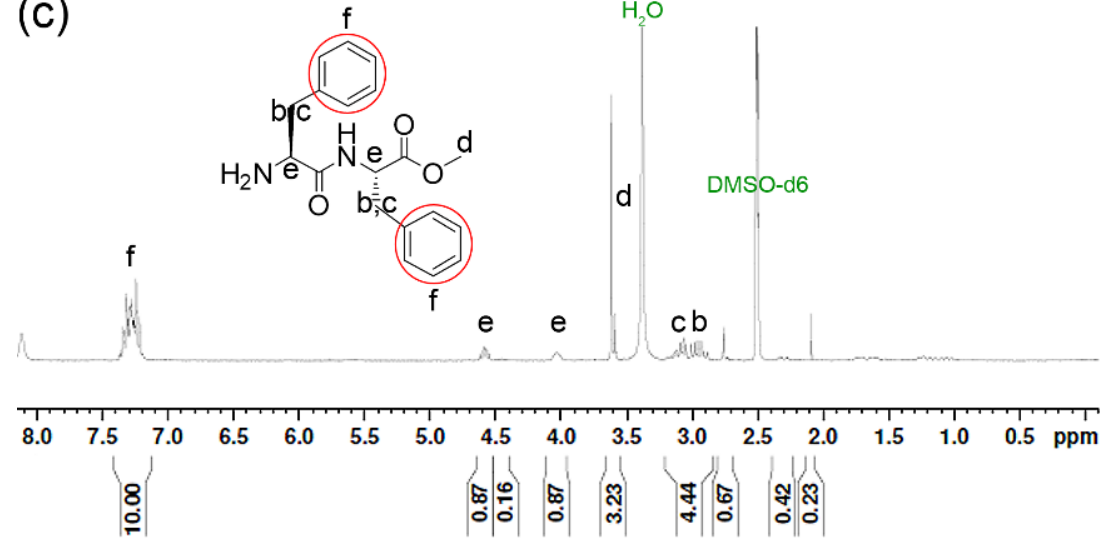

(d)

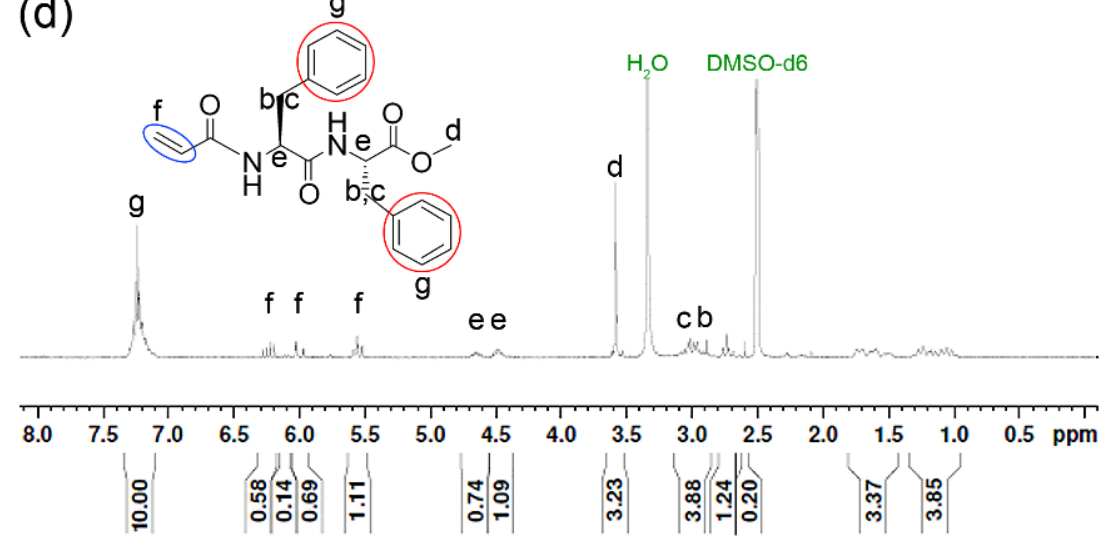

Figure S2. ${ }^{1} \mathrm{H}$ NMR spectra and chemical structures of (a) $N$-acryloyl-Phe-OMe, (b) Boc-Phe-Phe$\mathrm{OMe}$, (c) $\mathrm{NH}_{2}$-Phe-Phe-OMe, and (d) $N$-acryloyl-Phe-Phe-OMe. 


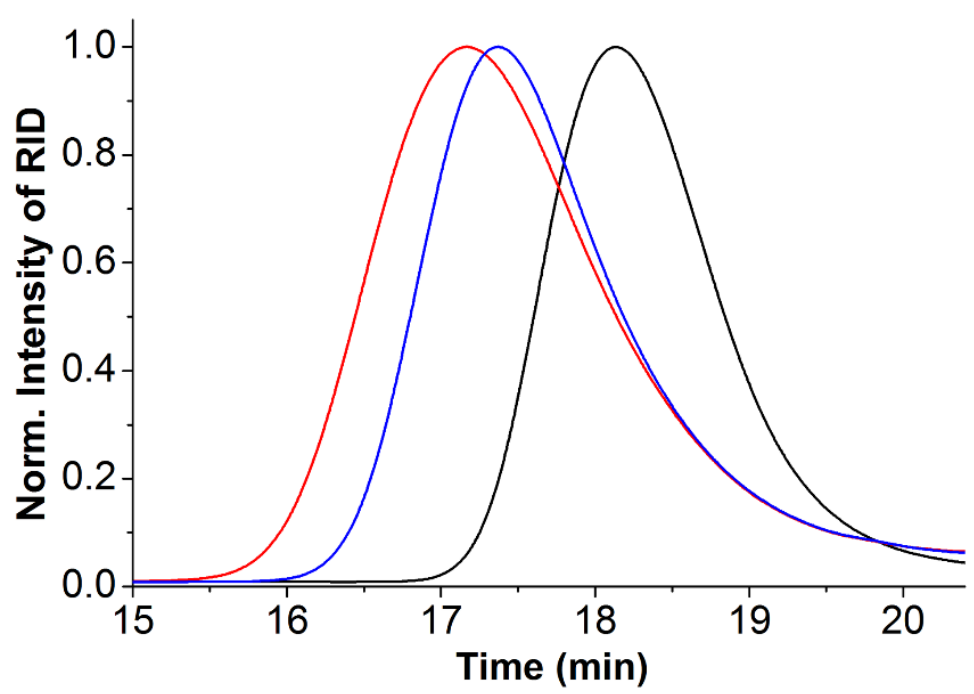

Figure S3. GPC chromatogram (RID trace) of poly(Phe-OMe) ${ }_{10}$ (black curve), poly(Phe-OMe) $)_{23}$ (red curve), and poly(Phe-Phe-OMe)11 (blue curve).

Table S1. Molecular weights of synthesized polymers.

\begin{tabular}{ccc}
\hline Polymer & $\mathbf{M}_{\mathbf{n}}(\mathbf{g} / \mathbf{m o l})^{\mathbf{a}}$ & $\mathbf{M}_{\mathbf{w}} / \mathbf{M}_{\mathbf{n}}{ }^{\mathbf{a}}$ \\
\hline poly(Phe-OMe $)_{10}$ & 2800 & 1.22 \\
poly(Phe-OMe $)_{23}$ & 5700 & 1.41 \\
poly(Phe-Phe-OMe $)_{11}$ & 4700 & 1.31 \\
\hline
\end{tabular}

${ }^{\mathrm{a}} \mathrm{M}_{\mathrm{n}}$ and PDI were determined by GPC with polystyrene standards. 
(a)

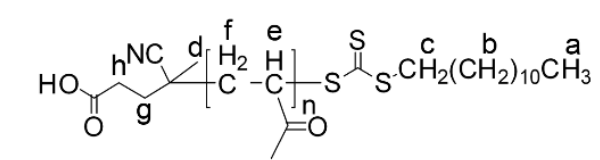
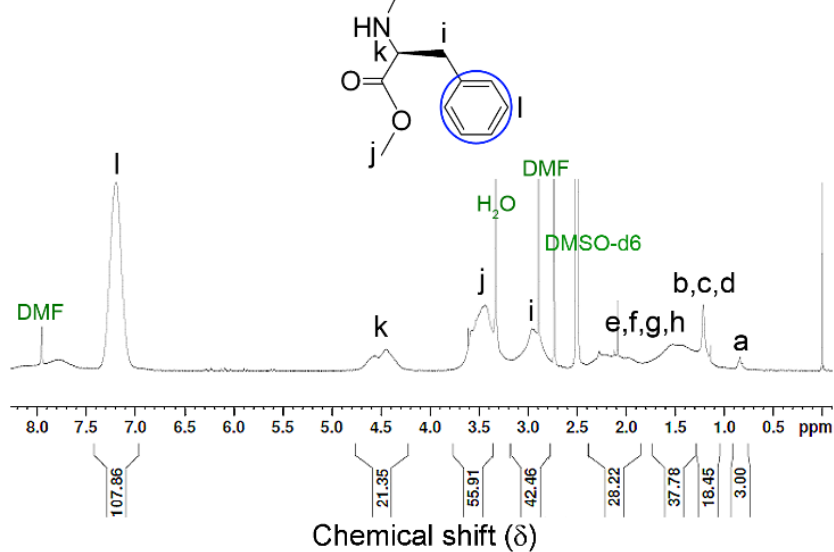

(b)

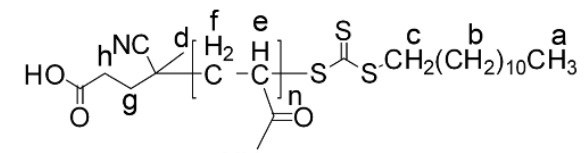
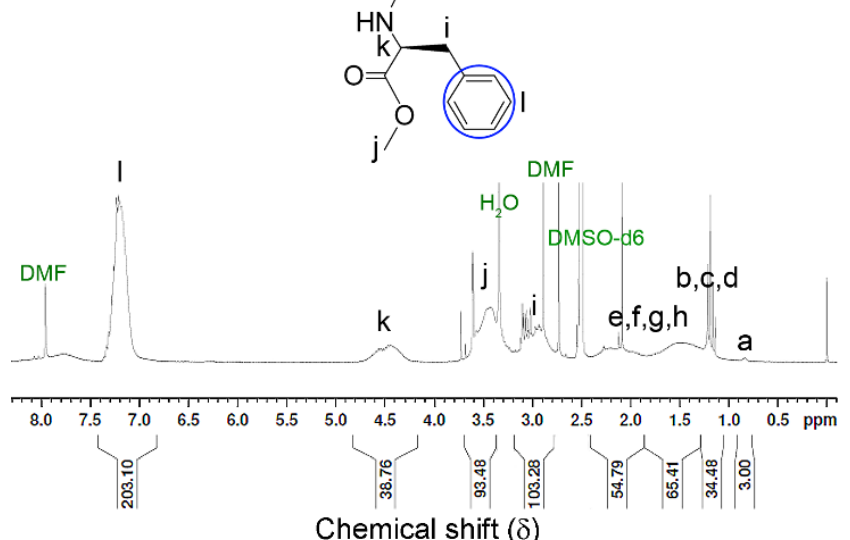

(c)

emical shift $(\delta)$

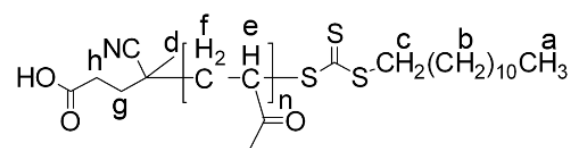
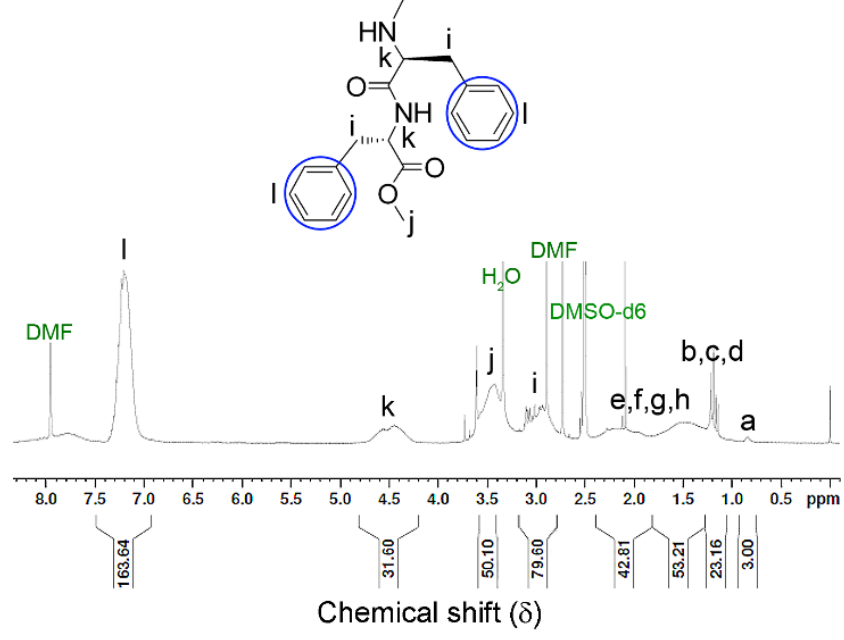

Figure S4. ${ }^{1} \mathrm{H}$ NMR spectra and chemical structures of (a) poly(Phe-OMe) 10 , (b) poly(Phe-OMe) 23 , and (c) poly(Phe-Phe-OMe) 11 . 
Table S2. DNA sequences.

\begin{tabular}{cc}
\hline Name $^{\mathbf{a}}$ & Sequence \\
\hline DNA1 & 5'-A3-ATCCTTATCAATATTCAA-FAM-3' \\
DNA1' & 5'-Cy3-TTGAATATTGATAAGGAT-3' \\
Thiol-modified DNA1 & 5'-SH-A10-ATCCTTATCAATATTCAA-3' \\
Thiol-modified DNA1' & 5'-SH-A10-TTGAATATTGATAAGGAT-3' \\
\hline
\end{tabular}

'DNA1 and DNA1' are complementary.

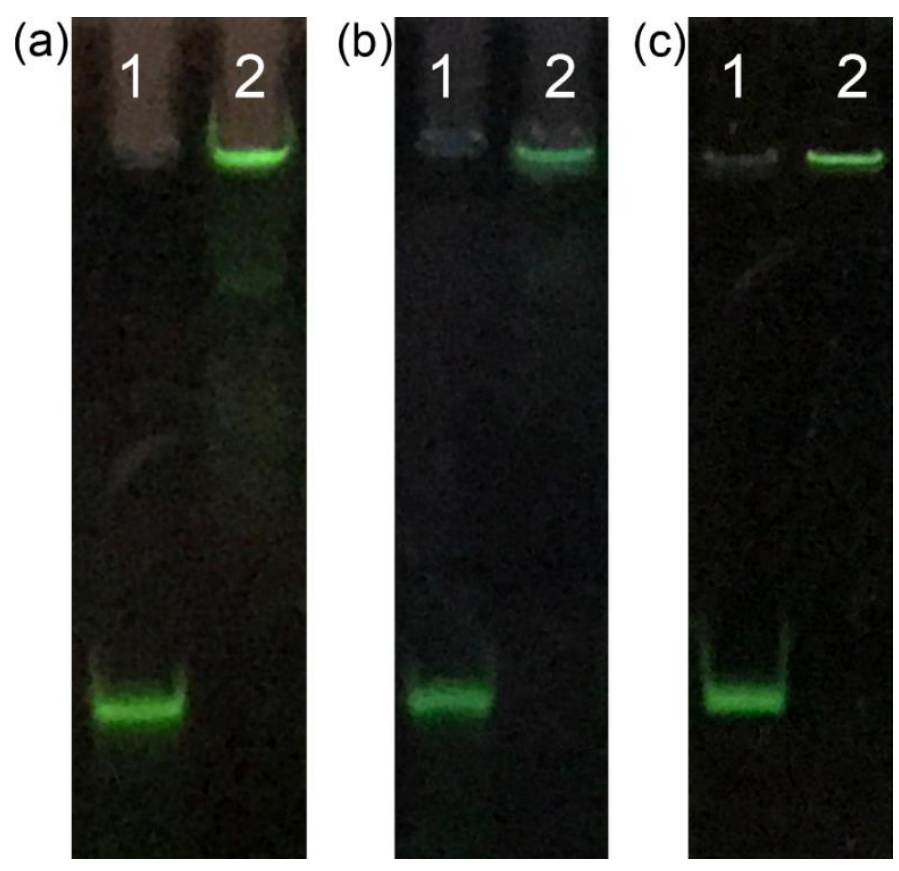

Figure S5. 15\% precast gel electrophoresis data. All lane 1: Plain DNA1, Lane 2: (a) DNA1-bpoly(Phe-OMe) ${ }_{10}$, (b) DNA1- $b$-poly(Phe-OMe) ${ }_{23}$, and (c) DNA1- $b$-poly(Phe-Phe-OMe) $)_{11}$. 
Table S3. Polarity index of organic solvents

\begin{tabular}{cc}
\hline Solvents & Polarity index $^{\mathbf{a}}$ \\
\hline 2-propanol & 4.0 \\
Methanol (MeOH) & 5.1 \\
Acetonitrile (ACN) & 5.8 \\
$N, N$-dimethylformamide (DMF) & 6.4 \\
Hexafluoro-2-propanol (HFIP) & $9.5 \pm 0.5$ \\
\hline
\end{tabular}

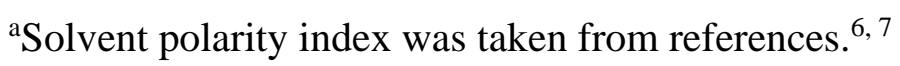

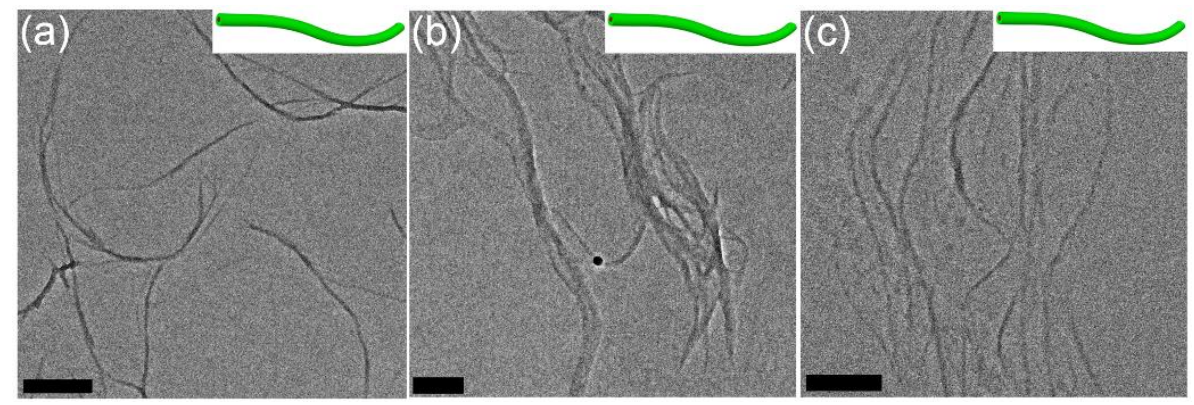

Figure S6. TEM images of one-dimensional nanostructures formed from (a) DNA- $b$-poly(Phe-OMe $)_{10}$ (F10DA), (b) DNA-b-poly(Phe-OMe) ${ }_{23}\left(\mathrm{~F}_{23} \mathrm{DA}\right)$, and (c) DNA-b-poly(Phe-Phe-OMe) $)_{11}\left(\mathrm{FF}_{11} \mathrm{DA}\right)$ in HFIP/water (1:4) (scale bars: $500 \mathrm{~nm}$ ). 


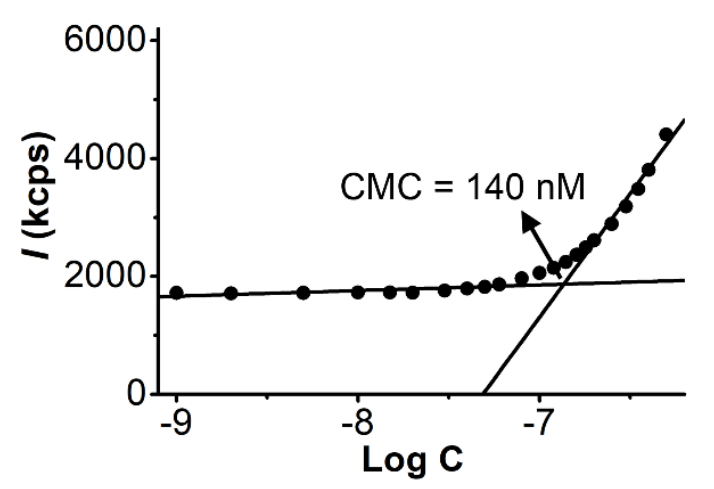

Figure S7. Light scattering intensity $(I)$ as a function of concentration $(C)$ for DNA- $b$-poly(PheOMe) ${ }_{23}$ assemblies prepared in HFIP/water (1:9). The critical micelle concentration (CMC) was determined to be $140 \mathrm{nM}$ from the data.

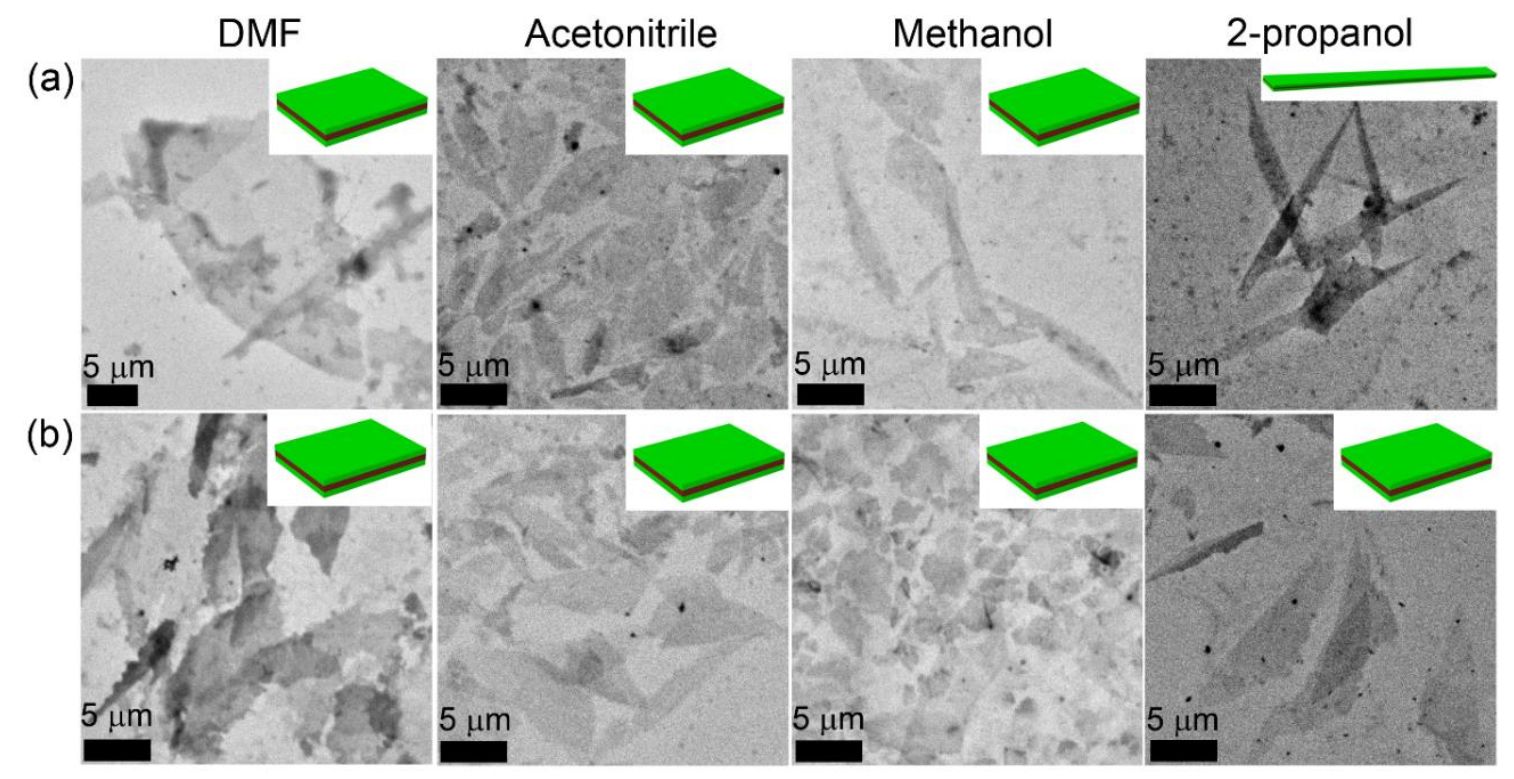

Figure S8. TEM images of (a) DNA- $b$-poly(Phe-OMe) $)_{10}$ and (b) DNA- $b$-poly(Phe-Phe-OMe $)_{11}$ assemblies prepared in DMF/water (1:9), ACN/water (1:9), MeOH/water (1:9), and 2-propanol/water (1:9). 

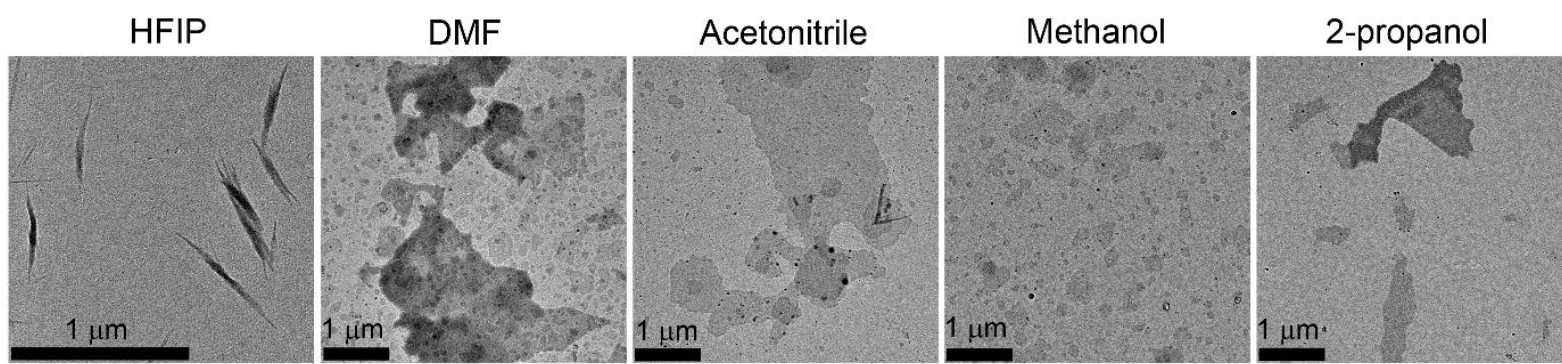

Figure S9. TEM images of poly(Phe-OMe) 23 assemblies prepared in HFIP/water (1:9), DMF/water (1:9), ACN/water (1:9), MeOH/water (1:9), and 2-propanol/water (1:9).
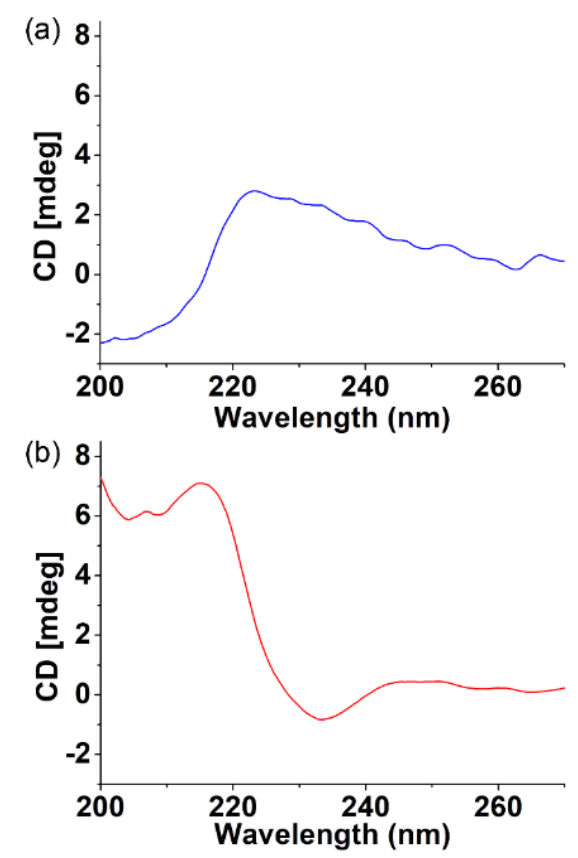

Figure S10. CD spectra of poly(Phe-OMe) 23 assemblies prepared in (a) HFIP/water (1:9) and (b) ACN/water (1:9). 

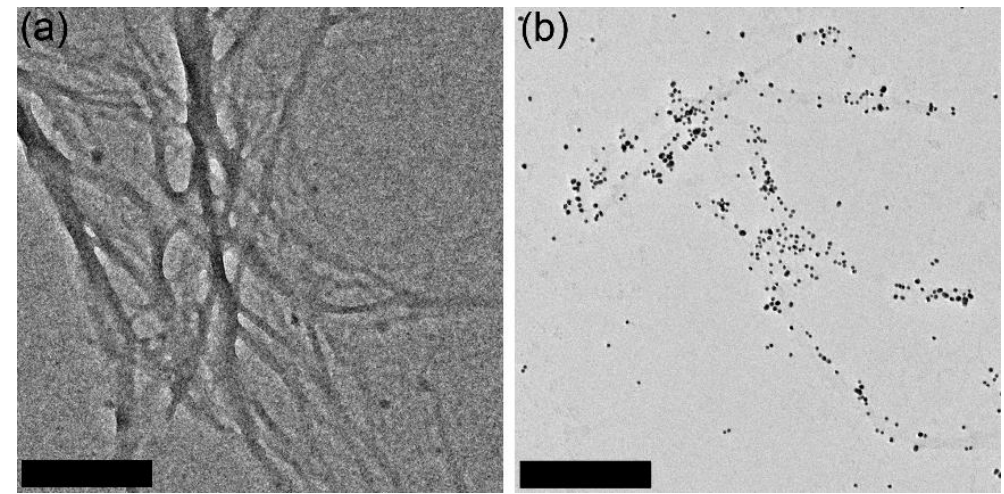

Figure S11. TEM images of one-dimensional nanofibers formed from DNA1- $b$-poly(Phe-OMe $)_{23}$ (F23 DA) (a) before and (b) after the addition of AuNPs-DNA1' (scale bars: $500 \mathrm{~nm}$ ). The experiments were carried out in 1:9 mixture of HFIP and $0.5 \mathrm{X}$ TBE buffer containing $50 \mathrm{mM} \mathrm{NaCl}$.
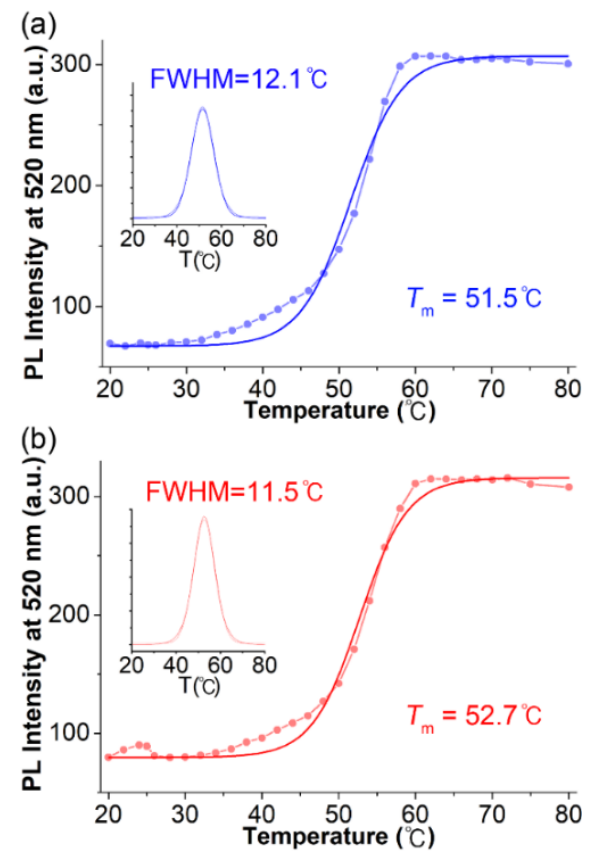

Figure S12. DNA melting transition curves of (a) DNA- $b$-poly(Phe-OMe) 23 nanofibers prepared in HFIP/water (1:9) and (b) DNA- $b$-poly(Phe-OMe) 23 nanosheets prepared in MeOH/water (1:9). The DNA hybridization was monitored by fluorescence resonance energy transfer (FRET) between FAM on DNA1- $b$-poly(Phe-OMe) 23 and $\mathrm{Cy} 3$ on single stranded complementary DNA (DNA1'). The recovery of fluorescence intensity is indicative of dehybridization between DNA1 and DNA1'. 


\section{REFERENCES}

(1) George, S.; Champagne-Hartley, R.; Deeter, G.; Campbell, D.; Reck, B.; Urban, D.; Cunningham, M., Amphiphilic Block Copolymers as Stabilizers in Emulsion Polymerization: Effects of the Stabilizing Block Molecular Weight Dispersity on Stabilization Performance. Macromolecules 2015, 48, 8913-8920.

(2) Topel, Ö.; Çakır, B. A.; Budama, L.; Hoda, N., Determination of Critical Micelle Concentration of Polybutadiene-Block-Poly (Ethyleneoxide) Diblock Copolymer by Fluorescence Spectroscopy and Dynamic Light Scattering. J. Mol. Liq. 2013, 177, 40-43.

(3) Turkevich, J.; Stevenson, P. C.; Hillier, J., A Study of the Nucleation and Growth Processes in the Synthesis of Colloidal Gold. Discuss. Faraday Soc. 1951, 11, 55-75.

(4) Liu, X.; Atwater, M.; Wang, J.; Huo, Q., Extinction Coefficient of Gold Nanoparticles with Different Sizes and Different Capping Ligands. Colloids Surf., B 2007, 58, 3-7.

(5) Storhoff, J. J.; Elghanian, R.; Mucic, R. C.; Mirkin, C. A.; Letsinger, R. L., One-Pot Colorimetric Differentiation of Polynucleotides with Single Base Imperfections Using Gold Nanoparticle Probes. J. Am. Chem. Soc. 1998, 120, 1959-1964.

(6) Reichardt, C.; Welton, T., Solvents and Solvent Effects in Organic Chemistry, Fourth Edition; WILEY-VCH Verlag GmbH \& Co. KGaA: Weinheim, 2011.

(7) Wang, Y.; Qi, W.; Huang, R.; Yang, X.; Wang, M.; Su, R.; He, Z., Rational Design of Chiral Nanostructures from Self-Assembly of a Ferrocene-Modified Dipeptide. J. Am. Chem. Soc. 2015, $137,7869-7880$. 